Article

\title{
Justifying Secession in Catalonia: Resolving Grievances or a Means to a Better Future?
}

\author{
Anwen Elias * and Núria Franco-Guillén \\ Department of International Politics, Aberystwyth University, UK; E-Mails: awe@aber.ac.uk (A.E.), \\ nuf@aber.ac.uk (N.F.-G.) \\ * Corresponding author
}

Submitted: 28 May 2021 | Accepted: 11 August 2021 | Published: 10 December 2021

\begin{abstract}
This article advances understandings of secessionist strategies by examining how and why secessionist movements make the case for creating a new sovereign state. It draws on new empirical data to examine the ways in which pro-independence parties in Catalonia have justified their calls for the creation of an independent Catalan Republic between 2008 and 2018. The findings challenge the widespread scholarly assumption that secessionist mobilisation is underpinned by grievancescultural, economic, and political-against the state. We find that arguments for an independent Catalonia rarely include cultural claims. Instead, independence is advocated as a way of resolving political and economic grievances and of creating a better, more democratic, and just Catalan society. Such justifications are highly influenced by the political context in which pro-independence parties try to advance towards secession. These insights advance on extant explanations of secessionist mobilisation by highlighting the distinctive nature of, and the motives for, secessionist claims.
\end{abstract}

\section{Keywords}

Catalonia; grievances; independence; pro-independence parties; secession; sovereign state

\section{Issue}

This article is part of the issue "Secessionism in Liberal Democracies: What Do We Really Know About the Explanations of Secessionism?" edited by Ferran Requejo (Pompeu Fabra University, Spain) and Marc Sanjaume-Calvet (Pompeu Fabra University, Spain / Open University of Catalonia, Spain).

(C) 2021 by the authors; licensee Cogitatio (Lisbon, Portugal). This article is licensed under a Creative Commons Attribution 4.0 International License (CC BY).

\section{Introduction}

Scholars of secession have generally assumed that secessionist mobilisation is underpinned by a sense of cultural, economic, or political grievance against the state, deriving from perceptions that a national community is being unfairly or unjustly treated in some way. This article challenges such grievance-based explanations of secession by providing new evidence of how and why secessionist movement justify their calls for the creation of a new sovereign state. It does so by examining the discursive strategies of pro-independence parties in Catalonia-Esquerra Republicana de Catalunya (ERC), Convergència Democràtica de Catalunya (CDC), and Candidatura d'Unitat Popular (CUP)-between 2008 and 2018. We argue that whilst grievance-based argu- ments are a key feature of the case made by these actors for independence, they are also (increasingly) accompanied by arguments that posit independence as a means of creating a better political and socio-economic future for the Catalan nation. Strikingly, and in contrast to the predominant expectation in much of the scholarship on secession, we find little evidence of cultural claims being used to justify Catalan independence. Catalan pro-independence parties' shifting arguments for secession seek to respond to the changing political contexts in which they try to mobilise popular support for independence.

The article advances on recent work on secessionist strategies in two ways. Firstly, it exploits the new Framing Territorial Demands (FraTerr) data set (Elias et al., 2021) on how regionalist actors in Europe have framed their 
territorial demands; this allows for a more systematic comparative analysis of secessionists' justification strategies than is provided by existing studies of individual political parties or movements (Abts et al., 2019; Dalle Mulle, 2017; Elias, 2019) and captures the broader range of arguments used and changing strategies over time which other datasets cannot (Griffiths, 2020; Griffiths \& Martinez, 2020). Secondly, the article draws on interviews with party representatives to provide the first exploration of the factors shaping secessionist parties' strategies for justifying secession; the analysis thus provides new insights into why, as well as how, secessionists make the case for creating a new sovereign state. As a result, the analysis of the Catalan case presented here significantly advances our understanding of the ways in which secessionists behave strategically to try to shape the dynamics and outcomes of secessionist processes.

In the next section, we review the extant scholarship on how secessionist movements justify their calls for the creation of a new state. The article then introduces the Catalan pro-independence parties that are analysed here and the data on which the analysis draws. The following sections evidence and seek to explain the complex political and economic case made for secession by Catalonia's pro-independence parties, where grievances are complimented by arguments that posit independence as a means to a better, more democratic, and just Catalan society. We conclude by considering the broader significance of these findings: They advance our understanding of the nature of and motives for secessionist behaviour and provide the basis for re-thinking the nature of on-going independence debates in Catalonia.

\section{Justifying Secession: Resolving Grievances or a Means to a Better Future?}

Secessionist conflicts are often highly polarised, characterised by competing arguments for and against the withdrawal of a territory and its population from an existing state to create a new one. In this sense, secession by its very nature raises the basic question of justification: "The perceived justice of the secessionist cause colours the opinions of potential support of members of the distinct community itself, the central government, foreign governments, and the international community" (Bartkus, 1999, p. 4).

Scholars of secession, however, have undertaken very little systematic study of the specific ways in which secessionist movements justify their calls for the creation of a new state. The focus instead has been on explaining secessionist mobilisation more broadly, and this work makes two assumptions about what drives such mobilisation. Firstly, secessionists are motivated by a sense of discontent with, or grievance against, the host state or majority population (Pavkovic \& Radan, 2007, p. 17); a sense of grievance is thus "always present in some way within an argument for secession" (Lecours, 2020, p. 145). From this perspective, seces- sion is understood as a group's response to the perception that "their" national community is somehow losing out from the existing social or political arrangements (Pavkovic \& Radan, 2007, p. 47; Sorens, 2008, p. 310). Calls for secession are thus understood to be an expression of discontent or frustration by a territorial community "often bound together by common claims or perceptions of discrimination, neglect, exploitation or repression" (Bartkus, 1999, p. 11).

Secondly, such grievances are assumed to manifest themselves along three dimensions: cultural, economic, and political. Cultural grievances arise from the desire to protect the seceding community's culture (Buchanan, 1991, p. 32). Threats to a community's culture may come from assimilation policies by a state intent on achieving cultural homogenisation, and a desire to preserve cultural distinctiveness in such a context was a key justification for secession in several Soviet republics during the early 1990s (Hesli et al., 1997). Similar attempts at the eradication of Kurdish culture by Turkey over several decades have been an important factor in the mobilisation of Kurds for secession (Bartkus, 1999, pp. 89-91; Sarigil \& Karakoc, 2016). In contrast, support for secession in Quebec during the 1980s was driven in part by the belief that French-speaking Quebeckers were not recognized as equal in Canada and that the French language was threatened (Pinard, 1992, as cited in Mendelsohn, 2003 , p. 512). Huszka (2013, p. 7) similarly finds evidence of feelings of cultural resentment feeding into secessionist movements' framing of their independence demands in the lead-up to the break-up of Yugoslavia. Whilst these examples indicate that the specific nature of cultural grievances may vary from case to case, scholars have mostly taken for granted that such arguments will be a feature of secessionist discourses given that these groups mobilise in the name of a group which is presumed to be culturally distinctive in some way (Pavkovic \& Radan, 2007, p. 18).

Economic grievances arising from the perceived economic differentials between the seceding territory and the rest of the state (Horowitz, 1981, pp. 171-172; Jenne et al., 2007, p. 543) are also expected to feature in secessionists' claims. In relatively richer regions, the frustration is argued to derive from the fiscal deficit between the region and the state, whereby the former pays more in taxes than it receives in expenditures (Hesli et al., 1997, p. 205; Sorens, 2005, p. 310). The presence of such a fiscal grievance has been found to be a feature of secessionist movements' discourses in places like Catalonia and Flanders (Dalle Mulle, 2017). Scholars have also argued that such a perception is an important driver of electoral support for secessionist parties (Álvarez Pereira et al., 2018; Sorens, 2005, 2008). In contrast, in relatively poorer regions, it is the sense of being neglected or exploited that drives secession "despite the costs it is likely to entail" (Horowitz, 1981, p. 174). Huszka (2013) finds, for example, that in the late 1980s pro-independence movements in Slovenia and 
Montenegro both argued that economic crisis and bad policies at the political centre were holding back their economic development.

Relatively less attention has been paid to political grievances, which express discontent with the territorial community's political status or rights in some way. In post-colonial contexts, for example, calls for independence have frequently been justified in terms of the denial of the nation's right to self-determination as a result of colonial occupation (Griffiths, 2020, pp. 7-8). In contrast, Saideman and Ayres (2000) have argued that events in the late 1980s and early 1990s in Czechoslovakia, Yugoslavia, and the Soviet Union suggest that groups facing discrimination or denied access to power and resources are more likely to want to "create a state that they control." In other cases-including Slovenia during the late 1980 s and Bougainville more recently-there is evidence of secession being justified in terms of basic human rights (Griffiths, 2020, pp. 6-7; Huszka, 2013). Finally, in advanced Western democracies, secessionists have often denounced the political failings of "un-democratic" states which deny the nation's right to self-determination (Dalle Mulle, 2017, p. 154; Della Porta et al., 2017), or which have repeatedly failed to accommodate demands for greater political autonomy (Basta, 2018, p. 1253; Lecours, 2020, p. 152).

Secession has thus generally been understood as a way of resolving grievances, where these arise from perceived unfairness or injustice(s) to which a group is exposed within a state. Much less attention has been given to alternative grounds on which the case for secession might be made. One of the first to do so was Dion (1996, p. 271), who argued that secessionist movements are rooted not just in fear inspired by the existing union but also "confidence inspired by secession" and the "sense that the group can perform better on its own and that secession is not too risky." More recently, new evidence has been brought forward of the importance of the latter kind of justifications for many secessionist movements in Western Europe. This work points to the justification of secession as a means of creating what the Scottish National Party (2019) has described succinctly as a "better future." In their study of social movements' justifications of secession during recent referendum campaigns in Scotland and Catalonia, for example, Della Porta et al. (2017) identify the use of both "diagnostic frames" anchored in perceptions of territorial grievance, as well as "prognostic frames" that posit independence as an opportunity to create new kinds of social and political relationships. A similar finding emerges from studies of the Flemish Nieuw-Vlaamse Alliantie (N-VA), whose political discourse both denounces the inadequacies of the existing state of affairs and emphasises a futureoriented message of hope and change (Abts et al., 2019, p. 855 ; Dalle Mulle, 2017, pp. 217-220). Similar claims have been identified by other work that has analysed the discourses of pro-independence parties in Quebec, Scotland, and Catalonia (Elias, 2019; Lecours, 2020).
This work gives rise to the expectation that secession may be justified in order to resolve territorial grievances, as well as being a means to create a different and better society within the framework of a new sovereign state. In the next section, we explore this expectation empirically with the use of a new dataset which permits a systematic and comparative analysis of the different arguments advanced by secessionist parties in one specific case-Catalonia-to make the case for independence.

\section{Justifying Secession: Evidence From Catalonia}

Across Western Europe, calls for secession have grown in prominence since the turn of the century (De Winter et al., 2018). Some long-standing secessionist actors have gained unprecedented electoral and political visibility; other autonomist parties have abandoned their moderate territorial positions and shifted to calling for independence instead, and new secessionist parties and civil society organisations have emerged in many places. Catalonia can be considered a paradigmatic example of this general trend: Catalan politics in recent years has been dominated by the question of independence as a result of strong electoral and societal mobilisation in favour of the creation of a Catalan Republic, leading to unofficial independence referenda being organised in 2014 and 2017 (Balcells et al., 2020; Cuadras Morató, 2016).

In this analysis, we examine how Catalan proindependence political parties represented in the Catalan parliament between 2008 and 2018 have sought to make the case for a new Catalan state. Three political parties are included in the analysis: CDC, which contested elections as part of Convergència i Unió (CiU) until 2015, and as part of the Junts per Catalunya (JxC) from 2016; ERC; and CUP. These parties first secured a majority of seats within the parliament in the 2012 regional election (Rico \& Liñeira, 2014). Such a majority was retained in the 2015-when CDC and ERC formed the alliance Junts per Si (JxS) - , 2017, and 2021 regional elections, albeit with some shifts in vote share and number of seats amongst the different parties (Guntermann \& Blais, 2020; Hedgecoe, 2021; Martí \& Cetrà, 2016). By comparing parties' strategies for justifying secession in a single political context, we can explore variation across secessionist parties and the similarities and differences between them. This is an appropriate strategy for an exploratory analysis which aims to probe how and why secessionists justify their calls for independence (Reiter, 2013). We focus on the period between 2008 and 2018, a decade which encompasses key developments in secessionist mobilisation: ERC's re-assertion of its secessionist position, the two attempts at holding an independence referendum, the Catalan Parliament's unilateral declaration of independence on 27 October 2017, and the subsequent response of the Spanish state (Balcells et al., 2020).

There are, however, important differences between these three parties in terms of their position on 
independence. ERC had profiled itself as a secessionist party since the late 1980s, although from the late 1990s it downplayed its call for independence and prioritised the reform of Catalonia's autonomy statute instead (Elias, 2015, p. 82). Independence was re-stated as the party's main goal from 2008 onwards in response to the failure of the statue reform process and strong civil society mobilisation in favour of secession from 2010 (Culla, 2013, p. 670). These developments, as well as the Spanish state's rejection of calls for greater fiscal powers for Catalonia during the early 2010s, also led CDC (then part of CiU, which was created in 1978 as an alliance between two parties [CDC and Unió Democràtica de Catalunya]) to commit to Catalan independence from 2012 onwards; hitherto, the party had advocated for the advancement of Catalan self-government within the Spanish constitutional framework (Elias, 2015). However, the shift in position also created internal tensions that resulted in the formal disbandment of CiU in 2015; $\mathrm{CDC}$ was re-branded as Partit Demòcrata Europeu Català (PDeCAT) in July 2016 and joined the JxC alliance in advance of the 2017 regional elections (Gray, 2020). Finally, the 2012 Catalan election was also significant in that it saw CUP-a grass-roots coalition of far-left pro-independence and anti-capitalist groups that had previously only contested local elections (Dalle Mulle \& Serrano, 2019, p. 643)-gain representation for the first time.

We examine how these three parties have justified their calls for Catalan independence by using the new FraTerr dataset (Elias et al., 2021). The dataset provides information on the kinds of territorial demands made by regionalist actors in 12 European regions during the period 1990-2018, and the frames used to justify these. The dataset is highly suited for analysing how secession is justified for two reasons. Firstly, it conceptualises frames as "justifications," understood as arguments that add political meaning to an issue or position by providing "a legitimating basis for taking up a specific stance" (Statham \& Trenz, 2012, pp. 128-129). Secondly, the dataset proposes a novel categorisation of the ways in which regionalist actors frame their demands as the basis for a systematic and comparative study of this aspect of regionalist mobilisation; the FraTerr coding scheme was informed by the extant literature on territorial politics and refined based on piloting using a sample of political documents from the FraTerr case studies (see Supplementary File). In this respect, the dataset offers a significant advance on inductive qualitative studies of secessionist actors' framing strategies (Abts et al., 2019; Dalle Mulle, 2017; Della Porta et al., 2017; Elias, 2019) and provides for a much broader range of possible cultural, economic, and political arguments for secession than have hitherto been proposed. Thirdly, by further coding the data on frames contained in the FraTerr dataset according to whether they articulate a sense of grievance or justify secession as a means to some kind of better future (see Supplementary File), we provide the first systematic examination of secessionists' use of such arguments. This differentiates our approach from that adopted by the only other dataset of secessionist claims available to date, namely the dataset of secessionist grievances (Griffiths \& Martinez, 2020). The latter starts from the assumption that "a grievance is what secessionists typically reference in their claims when issuing a declaration of independence" (Griffiths \& Martinez, 2020, p. 581) and proceeds to categorise secessionist arguments according to the kind of grievance invoked; the coding scheme's conceptualisation is thus unable to capture arguments that are not grievancebased. Fourthly, the timeframe of the FraTerr dataset also allows for an analysis of justification strategies over time, in contrast to other work which has focused on shorter periods/phases of secessionist mobilisation (Della Porta et al., 2017; Griffiths, 2020, p. 12; Griffiths \& Martinez, 2020).

\subsection{Framing Secession: A General Overview}

We start this analysis by considering the different dimensions to parties' justifications of Catalan independence, and the extent to which this case is made on cultural, economic, and/or political grounds. Across the proindependence movement as a whole and over the entire decade analysed, political justifications have been predominant ( $50.9 \%$ of all frames used), followed by socioeconomic ones (37.5\% of all frames used). This general pattern holds for the ERC, CDC (in its various forms), and CUP, as indicated in Figure 1. In contrast, the relatively limited use made by these actors of cultural arguments is striking, and these are completely absent from the JxS manifesto agreed by ERC and CDC for the 2015 Catalan election. Other types of frames not falling into these three broad categories were also marginal in parties' discourses overall. In general, the case for Catalan independence has thus predominantly been made in political and (to a lesser extent) socio-economic terms, with cultural justifications of marginal importance.

Given their salience, the rest of the analysis focuses on political and socio-economic justifications, in order to understand: (a) the specific types of political and socio-economic frames used over time and across parties, and (b) the extent to which these articulate political/economic grievances against the state or articulate a vision for a better political/economic future. A first impression of the latter is suggested by Figure 2, which shows the relative salience of grievance vs. better future arguments in pro-independence parties' political and socio-economic framings of independence. Just over half of the political frames used posit independence as a means to a political transformation of Catalan society; a significantly greater proportion (65\%) of economic frames are presented in this way. This initial finding challenges the focus of much of the secession scholarship on the assumed grievances underpinning such mobilisation; the remainder of the discussion in this section analyses 


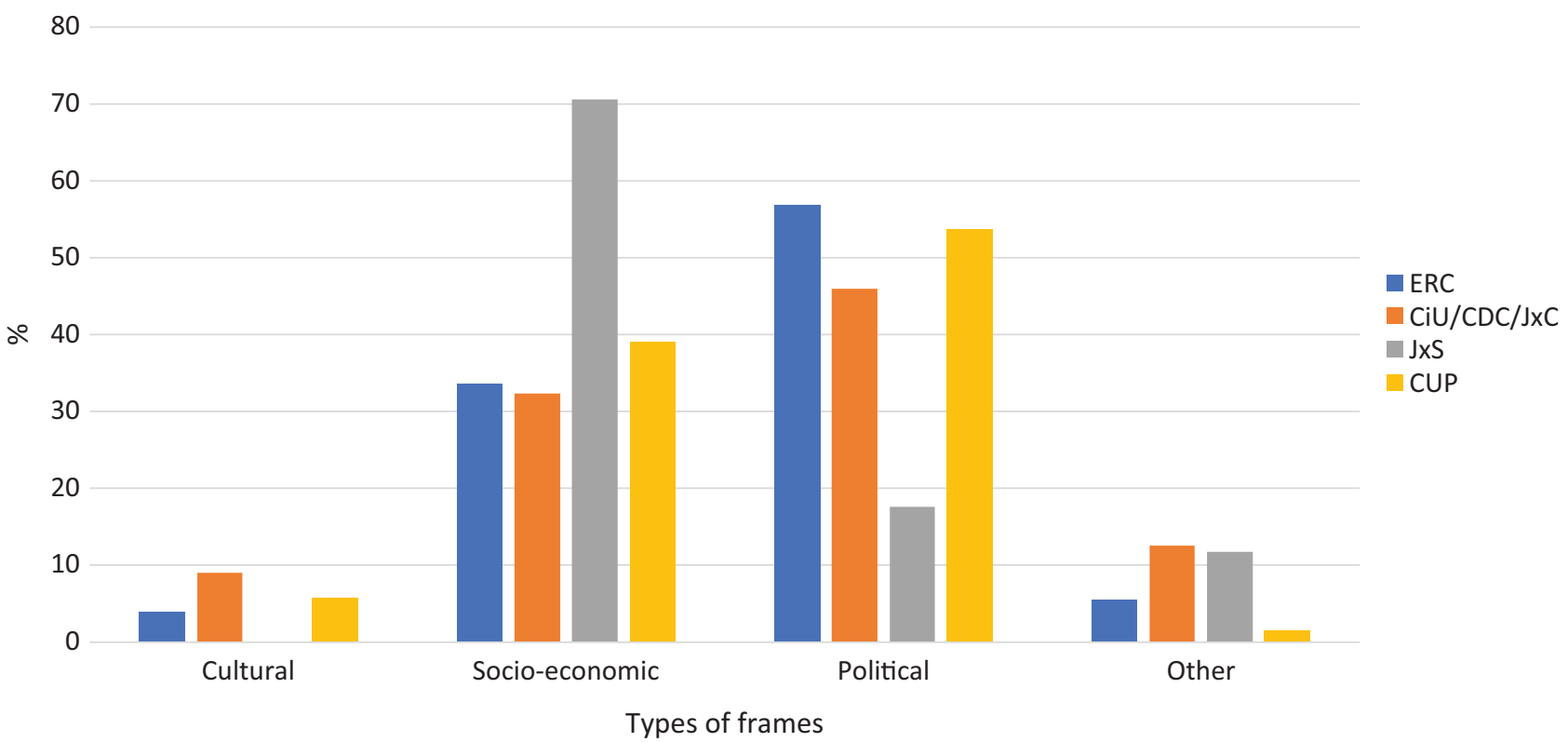

Figure 1. Catalan pro-independence parties' justifications of secession, 2008-2018.

the specific way in which such arguments are deployed in the discourses of Catalan pro-independence parties.

\subsection{Catalan Pro-Independence Parties' Political Justifications for Secession}

Figure 3 summarises the specific types of political frames used by the pro-Catalan parties between 2008 and 2018 . The data points to a clustering around specific types of political arguments. A first observation is that, with the exception of JxS, all parties use arguments expressing discontent with, and attributing blame for, the territorial status quo. Such frames are by their nature expressive of a sense of grievance against the existing territorial arrangements, and their specific content reflect key developments in Catalan politics in the decade being analysed and that have catalysed secessionist mobilisation. For example, through repeated references to the failed reform of Catalonia's Statute of Autonomy and the Spanish government's rejection of a new fiscal agreement, ERC vents its frustration at the fact that "everything has been tried, in vain, to find a fit for Catalonia within the state that respects its national and cultural particularity and allows for its social and economic development" (ERC, 2014, p. 5). Similar arguments are advanced by $C D C$ in its various forms from 2012 onwards, although these remain relatively less used than the other arguments outlined above $(7.8 \%$ of all political frames used). Both ERC and CDC blame the Spanish state in the hands of successive Spanish

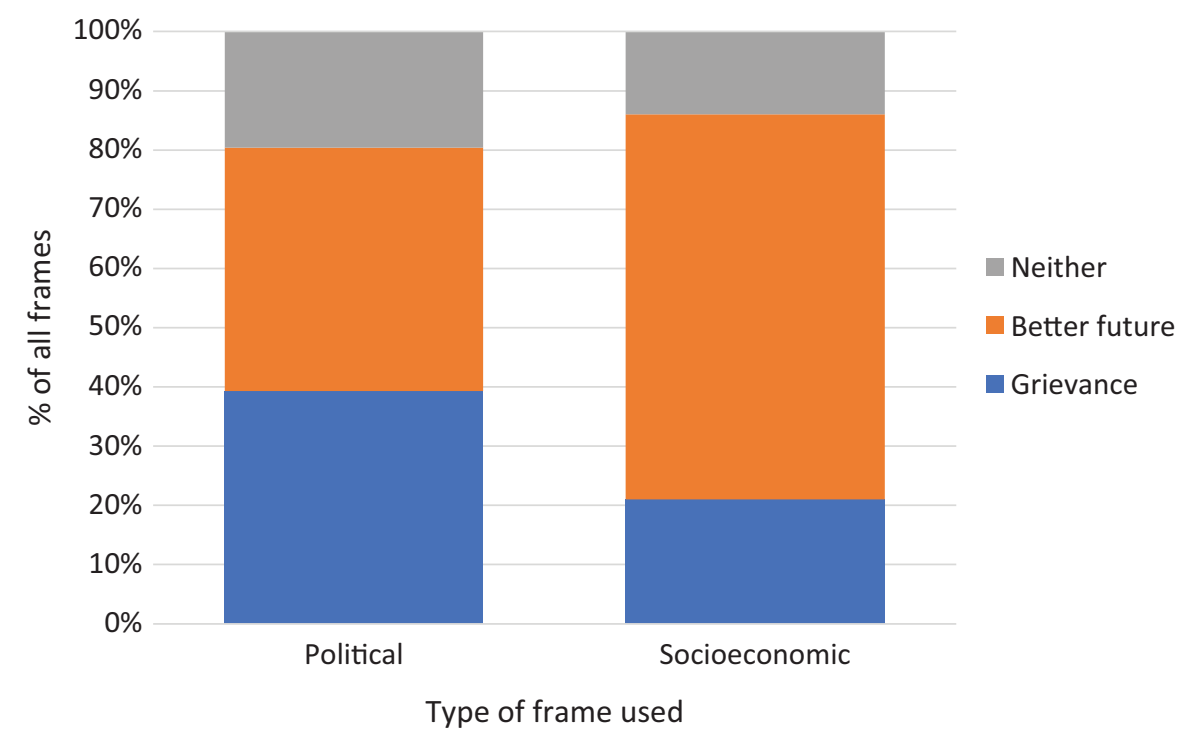

Figure 2. Catalan pro-independence parties' framing of independence as grievance vs. better future, 2008-2018. 


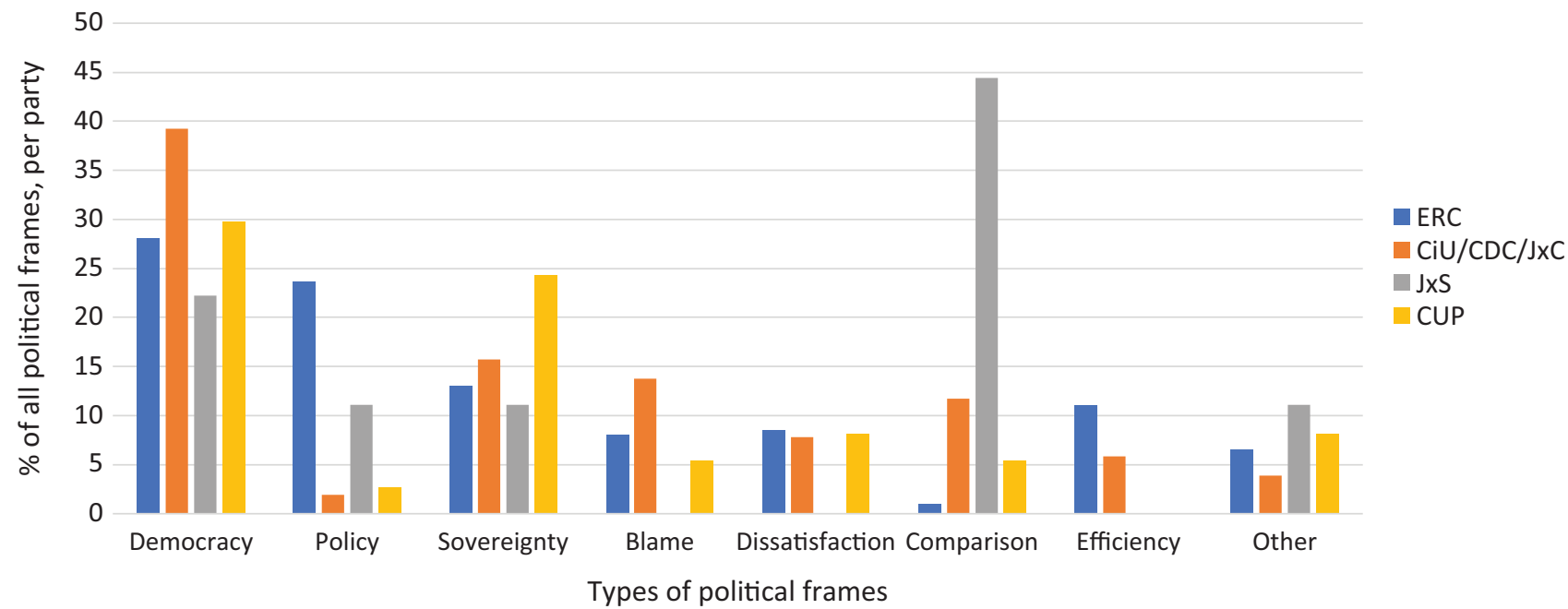

Figure 3. Catalan pro-independence parties' political justifications of secession, 2008-2018.

governments, and (for ERC in particular) Spain's statewide parties who have failed or refused to acknowledge Catalonia's right to decide on how it is governed. In addition, CUP singles out previous Catalan governments for criticism, for their failure to advance in the creation of a Catalan Republic after the Catalan parliament approved a Declaration of Catalan Independence on 27 October 2017 (CUP, 2017, p. 14). In this latter period, ERC also links such criticisms to increased assertions of the sovereignty of the Catalan people and its right to self-determination (see Figure 2). Whilst such claims are present in the party's pro-independence discourse during the 1990s, they emerge more strongly in response to the perceived refusal of the Spanish state to recognise Catalans' "right to decide" in recent years: "The state is a wall that refuses to recognise the sovereignty of Catalonia. No Statute, no Economic Agreement, no independence referendum....We cannot wait any more" (ERC, 2015, p. 2).

However, such dissatisfaction and blame frames are far from being the most used arguments in the Catalan context. Much more important are arguments relating to the quality of the democratic and political system in some way; this is the most used political frame by CiU/CDC/JxC (39.2\%), CUP (29.7\%), and ERC (28.1\%) to justify Catalan independence. On the one hand, such "quality of democracy" arguments are expressed as a grievance against the democratic functioning of the Spanish state, as exemplified by ERC's argument that independence is necessary because Spain's "democracy that doesn't work" (ERC, 2011, p. 131). Such an argument is amplified and expressed more harshly by CUP from 2012 onwards, with criticism of Spain's failing democracy repeatedly employed to advocate "rupture" from the repressive "laws of the 1978 Spanish Constitution and the monarchic regime inherited from the Franco period" (CUP, 2015, p. 7).

On the other hand, arguments making reference to the "quality of democracy" can also be framed more positively, and there is evidence of parties increasingly focusing on the democratic credentials and potential of a future Catalan Republic. For example, both ERC and (especially) CDC argue repeatedly for the legitimacy of such a Republic given the democratic process through which it is being created: "For the first time in many years a clear majority of Catalans, through the force of their votes, has given the Catalan parliament a clear mandate: to start the process of building Catalonia's own state" (CiU, 2015, p. 12). Both parties, but ERC most consistently, also justify independence in terms of the opportunity it provides to create a different and better democracy: "A Catalan Republic is an opportunity to build a different way to do politics based on the right to decide and a collaborative democracy in which all citizens become responsible for the good functioning of the Republic" (ERC, 2017, p. 91). As implied here, both ERC and CDC also frequently posit a link between the democratic credentials of an independent Catalonia and giving voice to a "sovereign" Catalan people; in this respect, independence equates to granting Catalans their right to "take our own decisions" (CiU, 2012, p. 12). Such themes were also a key feature of the joint manifesto agreed by the JxS coalition in 2015 , and which set out a positive vision of "the Republic that we want" (JxS, 2015, p. 10).

Our data also evidences the additional ways in which Catalan pro-independence parties have sought to make a clearer, more detailed, and positive case for independence. In particular, novel justifications that focus on the specific policy opportunities for a future independent Catalonia are deployed. In ERC's case, these are captured by the "policy" frame where specific policy goals are identified as ones that can be achieved as a result of independence; these account for $23.6 \%$ of all political frames used by the party in this period. Such arguments serve to set out the specific policy innovations that a Catalan Republic would pursue, often framed in terms of the "transformation" of Catalan society (ERC, 2017, p. 94) and the pursuit of a "new," "different," or "our 
own" model of policy-making (ERC, 2012, 2017). In a similar vein, arguments about "efficiency" are also deployed (accounting for $11.1 \%$ of all political frames used), to imply that independence will enable greater efficiency in all aspects of political decision-making:

We need our own state to build a new Catalonia, with an agile and efficient public administration, with simple operational structures and at the same time coordinated with all other parties involved in the management of cultural heritage, from tourism, education, public works and urbanism etc. (ERC, 2012, p. 163)

Albeit in more general terms, CUP deploys a similar line of argument bound up with the notion of Catalan sovereignty, a frame which accounts for $24.3 \%$ of all political frames used by the party. It thus argues for a postindependence "programme of popular sovereignty, that is, not subject to any power other than the voice of the people to decide on everything that affects us: politics, energy, food, urbanism, health, education etc." (CUP, 2017, p. 46).

\subsection{Catalan Pro-Independence Parties' Socio-Economic Justifications for Secession}

Figure 4 summarises the specific types of socioeconomic frames used by pro-independence Catalan parties to justify independence. For the whole period analysed, arguments referring to social justice predominate. Such a frame is the most used by CiU and its successors as well as by ERC and CUP; it is only in the JxS 2015 manifesto that another frame-economic prosperity-is more salient. Beyond this general trend, however, justifications on the basis of social justice also take different forms.

On the one hand, for CUP and ERC a key theme is independence as a solution to the perceived social injustices caused by Catalonia's position within the Spanish state. For the former, these derive from a system of "capitalism that generates misery and a patriarchy which imposes inequality" (CUP, 2015, p. 1). In this vein, the party's frequent use of "crisis" frames (see Figure 3) reflects its argument that the 2008 financial crisis has made independence even more necessary as the only means of achieving "social emancipation" (CUP, 2017, p. 2). In contrast, for ERC a persistent grievance in this respect is linked to so-called "fiscal plundering," whereby the Spanish government is repeatedly denounced for extracting more economic resources from Catalonia than the region received in investment and services (ERC, $2008,2011,2017)$. The general goal of creating a more just and equal society, where Catalans can "live better" (ERC, 2012, p. 39), is re-stated in the context of the financial crisis at the end of the 2000 s, in the following terms:

The crisis of the fiscal deficit prevents us from positioning ourselves as a rescue country, a country with a surplus, a country with levels of work and wellbeing according to the work and the wealth we know how to produce....We are [for]... a Catalan Republic... with tools and resources to solve the crisis, create jobs and build a welfare state. (ERC, 2011, p. 4)

However, alongside this grievance-driven discourseand increasingly from the mid-2010s onwards-all parties seek to advance a more positive vision of postindependence Catalonia that places social transformation at its core. For example, a common theme in ERC's manifestos is that "the purpose of having our own state is to guarantee the quality of life of all Catalans and improve their social wellbeing" (ERC, 2012, p. 909). CiU and its successors and (especially) CUP go even further in arguing that independence and social transformation are inextricably linked: "They are two processes that are inseparable one from the other" (CUP, 2012, p. 1; see also CDC, 2016; CiU, 2012, 2015; JxC, 2017). This shift of emphasis is supported with a shared commitment to,

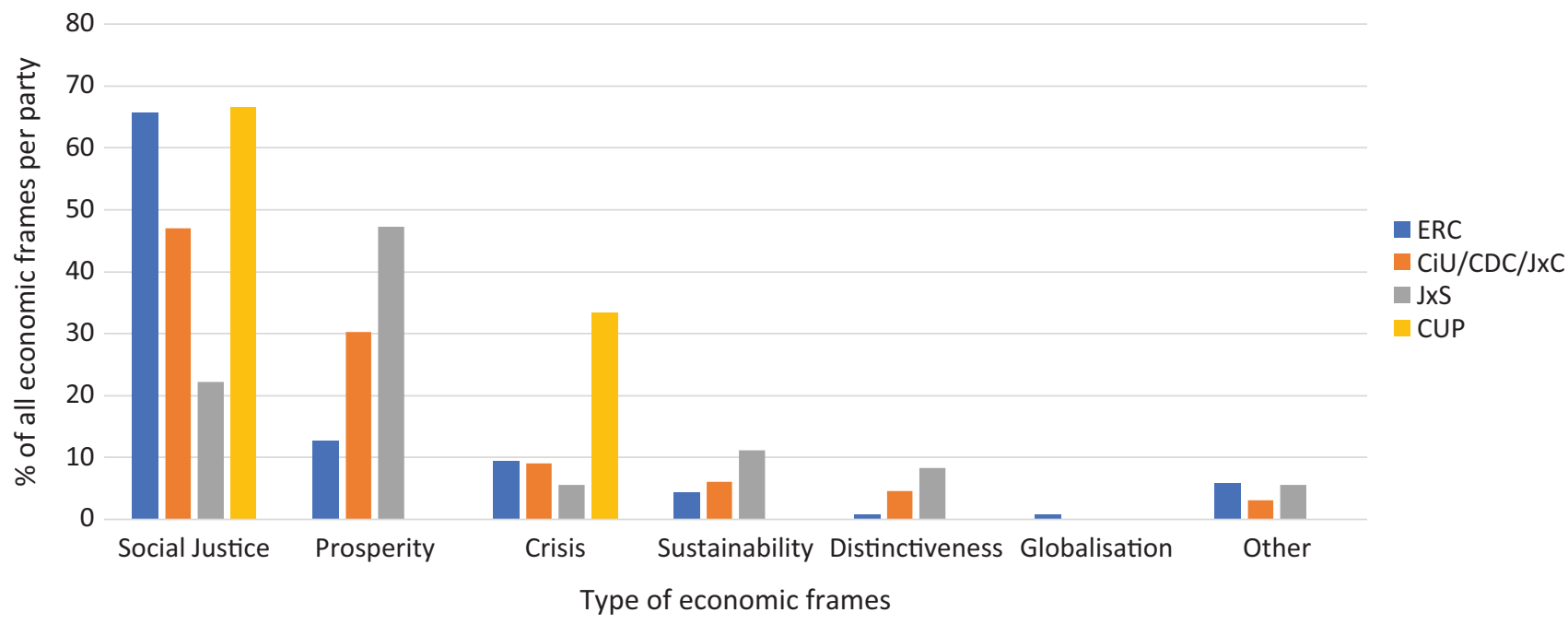

Figure 4. Catalan pro-independence parties' socio-economic justifications for secession, 2008-2018. 
for example, securing gender equality, a guarantee of social rights, and a better quality of life in a future Catalan Republic. However, it is in ERC's manifesto for the 2017 Catalan elections that most detail is provided on "the model of Republic that we want" (ERC, 2017, p. 8) with a key priority being "policies... aimed at making a reality a Catalan Republic with worthy public services, that represents a better quality of life for all citizens and that adopts a model that fights against structural poverty" (ERC, 2017, p. 10).

After social justice frames, those referring to economic prosperity are the most used, albeit to different extents by different parties. For example, they account for $33.3 \%$ of the socio-economic frames used by CiU and its successors, and the most used frame in the JxS manifesto. In contrast, they are much less used by ERC during this period ( $12.8 \%$ of all socio-economic frames) and are completely absent from CUP's discourse. There are also important differences in how such arguments are used. On the one hand, and as with social justice frames, there is a tendency to use them in conjunction with a critique of central government (and, to a lesser extent, EU) economic policies in the region. In particular, and especially in the context of the financial crisis, ERC takes issue with the impact on the productivity of the Catalan economy. On the other hand, the issue of prosperity is also invoked in parties' more recent efforts to map out their vision for a future Catalan Republic. Both ERC and CiU thus advance a common argument that independence can lead to greater prosperity, with the former also frequently linking this to achieving social justice. As suggested above, JxS is also distinctive in emphasising the economic viability of a future Catalan Republic based on the experiences of other comparably-sized countries:

Most economic indicators demonstrate Catalonia's ability to be at the forefront of economic progress, not only on a European scale, but also globally and that is why we can say that....Catalonia already has the full capacity to get by on its own. (JxS, 2015, p. 17)

\section{Discussion: Explaining Catalan Secessionists' Justifications of Independence}

The analysis in the previous section evidenced the ways in which justifications of secession vary across different pro-independence parties and over time. Nevertheless, two general trends can be identified. Firstly, secessionist discourses feature arguments for independence that express both grievances against the Spanish state and a positive vision for a future Catalan Republic; the latter also become more prominent over time and are a particularly salient feature of secessionist discourses during the 2010s. This finding challenges the assumption in much of the scholarship that secession is mobilised exclusively or primarily by perceptions of territorial grievance, as argued in Section 2. Secondly, such justificationswhether grievance-focused or future-orientated-draw almost entirely on political and economic arguments. Little consideration is given to the cultural dimension that is generally assumed by scholars to be a key dimension of secessionist mobilisation. In this section, we draw on interviews with party representatives to explore the factors that shape the types of arguments secessionists use to make the case for independence (for further detail on the interviews undertaken, see Supplementary File). Three factors emerge as being particularly significant.

Firstly, public opinion in relation to secession arguably pushes parties to play down some justifications for secession and emphasise others. In the words of one CDC interviewee, "you position yourself politically based on the demands that exist in society" (CDC interview, 12 March 2020). This is not surprising given that, in established democracies, majority support is usually a necessary (but not always sufficient) condition for secession (Dion, 1996; Lecours, 2020). Thus, for example, interviewees pointed to the constraints arising from the specific nature of the Catalan electorate, reflecting its highly diverse composition as a result of high levels of Spanish and international migration into the region during the twentieth century. In such a context, justifying secession using cultural arguments (especially those relating to the Catalan language) is also very risky since "all citizens must vote and... placing language issues on the political agenda can be divisive." In contrast, justifications that appeal to all "citizens of Catalonia" are much more likely to have broad appeal (ERC interviews, 2 and 4 March, 2020). The down-playing of cultural arguments is thus a deliberate strategy in spite of the fact that, in contemporary Catalan society, issues of language shift and normalisation remain major challenges (ERC interview, 2 March 2020). Interviewees from all parties also noted that an increase in social discontent after the 2008 financial crisis incentivised the greater use of social justice arguments for secession in recent years. At the same time, strong popular disillusionment with the failure of the statute reform process from 2010 onwards also informed parties' emphasis of arguments expressing dissatisfaction with the state's failure to accommodate Catalonia within Spain and those asserting the legitimacy of efforts to advance independence via democratic means. Such a context also informed the use of arguments asserting Catalonia's "right to decide" for itself on how it should be governed since "this went down well with people" opposed to Catalonia's treatment by Spain but not supportive of Catalan independence (CDC interview, 13 March 2020).

But we also find evidence of the role of public opinion may play in shaping parties' emphasis of grievance or future-orientated arguments. For example, we note in Section 3 the grievances articulated in relation to Catalonia's fiscal deficit relative to the rest of Spain. Mostly found in ERC's manifestoes, the party's interviewees also noted the strong pressure to re-frame their discussion of this issue in the context of a diverse Catalan electorate as described above. In particular in the eyes of 
voters who still have family links in other parts of Spain, "talking about the fiscal deficit is problematic [because] there's a danger that they say we lack solidarity" with Spain's poorer regions (ERC interview, 4 March 2020). Others expanded on this logic by noting that "we have made the issue more positive by saying what we could do with [more fiscal resources], we could provide more social policies" (ERC interview, 2 March 2020).

Secondly, the necessity to differentiate a party from pro-independence competitors also has a bearing on how calls for independence are framed: "When new actors appear with whom you have an electoral border and you're competing, yes, it can make you change your message" (ERC interview, 4 March 2020). Party ideology was cited by several interviewees as one basis on which such differentiation could be established. On the one hand, parties distinguish themselves by their left-right positions. Both ERC and CUP position themselves as left-wing parties and compliment their commitment to Catalan independence with the pursuit of "social justice and equality" (ERC, 2012, p. 7) and "socialist transformation" (CUP interview, 1 May 2020). In contrast, CDC's greater emphasis of economic prosperity frames arguably reflects the centre-right ideological profile of the federation-CiU-that it belonged to until 2015 (Barrio \& Barberà, 2006); an interviewee from PDeCAT thus noted his party's preference for talking about Catalan independence using a "different language" to that of the left, one that emphasises the "conditions for investment and the conditions for prosperity" that Catalonia offers (PDeCAT interview, 2 March 2020). On the other hand, CUP's distinctive anti-system values provides a further means of differentiating itself from ERC on the left of the political spectrum. CUP's framing of independence-and its reliance on grievance-based arguments articulating dissatisfaction with the Spanish political system-reflect its positioning as an anti-colonialist, anti-capitalist party. From this perspective, the party's calls for "democratic rupture as the only real possibility of accessing sovereignty" (CUP interview, 1 May 2020) is a very distinctive discourse to that espoused by ERC which, as a party in (or aspiring to) regional government, has sought to prioritise a "more mature" discourse that departs from a position of respect for "democratic principles" (ERC interview, 2 March 2020).

Thirdly, the prospect of holding a referendum on independence creates an incentive for secessionist parties to articulate a more detailed and positive case for creating a new state. As argued by Lecours (2020, p. 144), "a central aim of secessionist actors during an independence referendum campaign is to convince members of the minority national community of the desirability of secession." That such a pressure was felt by the parties examined here is most clearly expressed by ERC interviewees who referred to the 2012 Catalan election as a turning-point in the party's discursive strategy. With the election of a pro-independence majority of Catalan representatives, the party's focus shifted onto creating a "programme of state" that set out in detail the policy innovations that would be pursued in a future Catalan Republic; this strategy aimed at "the social growth of independence with a view to a hypothetical referendum" (ERC interview, 2 March 2020).

Justifying secession in such terms also makes strategic sense given that studies of referendum campaigns in Quebec and Scotland have suggested that pro-independence parties are usually confronted with risk-averse voters who tend to favour the constitutional status quo (Liñeira \& Henderson, 2019; Nadeau et al., 1999) and political parties opposed to secession whose campaigns tend to focus on the risks and high costs of such a decision (Lecours, 2020; Mitchell, 2016). However, the Catalan case differs from these examples in a key respect: Whilst the UK and Canadian governments did not question the legitimacy of the referendum, the Spanish government has strongly contested the legality and constitutionality of such efforts (Balcells et al., 2020). In particular, interviewees noted the Spanish government's suspension of Catalan autonomy in October 2017 after a unilateral declaration of independence was approved by the Catalan parliament, as a fundamental change in the context in which the case for secession had to be made: "We stopped fighting for independence and started for democracy" (CUP interview, 5 March 2020). Whilst all pro-independence parties inevitably framed such a decision using arguments strongly critical of the state's approach and (as noted in Section 3) re-asserted Catalonia's democratic "right to decide," there were also important differences between them. On the one hand, ERC preferred to reiterate its "positive message" aimed at reinforcing an electoral and social majority in favour of independence (ERC interview, 2 March 2020); on the other hand, JxC and (in particular) CUP have retreated from such a better future narrative in an attempt to tap into growing disenchantment with the Spanish political system: "We believe that we must make a speech not about implementation of the Republic, but about a new clash with the state" (CUP interview, 5 March 2020). The Catalan experience thus suggests that a third factor shaping pro-independence parties' justifications of secession is the political context in which a referendum on independence is pursued.

\section{Conclusion}

In undertaking a systematic analysis of Catalan proindependence parties' justifications of independence using newly available data, this article provides for a more comprehensive understanding of the nature of and motives driving secessionists' strategic behaviour. Our findings demonstrate that, in their political discourses, secessionists deploy justifications focused on grievances against the state alongside arguments that posit independence as a means to a better political and economic future for the territory. Any case for independence arguably must, of necessity, articulate a sense of 
grievance with the status quo in order to justify why radical change is necessary; however, such grievance-based arguments are not always sufficient to mobilise public support for the creation of a new sovereign state. The analysis of the Catalan case provides new insights into the different political pressures that come to bear on proindependence parties at different phases of secessionist mobilisation. As a result, secessionists' justifications for independence are more complex and contextual than has hitherto been acknowledged: arguments shift across actors and over time in response to the specific political conditions in which secessionist mobilisation occurs. In order to further probe such dynamics, future research should focus on expanding the scope of empirical analysis beyond the Catalan case.

The empirical findings also provide grounds for re-thinking the drivers of secessionist mobilisation in Catalonia where grievance-focused explanations continue to predominate. In his account of the rise of the pro-independence movement, for example, Dowling (2017, p. 88) notes that "the intense mobilisation of Catalan independence is inexplicable without national identity as an explanatory variable....As an untried political solution to the grievances of Catalonia." A similar explanatory role for identity-based grievances is posited in other work. However, the analysis presented here finds that secessionist parties themselves have sought to present the case for Catalan independence in very different terms. Future research should expand the empirical analysis beyond pro-independence political parties to explore the extent to which these findings hold for the Catalan pro-independence movement more broadly.

\section{Acknowledgments}

This research has received funding from the European Union's Horizon 2020 research and innovation programme under grant agreement no 726950 . This article reflects only the authors' views and the European Commission is not responsible for any use that may be made of the information it contains.

\section{Conflict of Interests}

The authors declare no conflict of interests.

\section{Supplementary Material}

Supplementary material for this article is available online in the format provided by the author (unedited).

\section{References}

Abts, K., Dalle Mulle, E., \& Laermans, R. (2019). Beyond issue diversification: N-VA and the communitarisation of political, economic and cultural conflicts in Belgium. West European Politics, 42(4), 848-872.
Álvarez Pereira, B., Portos, M., \& Vourdas, J. (2018). Waving goodbye? The determinants of autonomism and secessionism in Western Europe. Regional Studies, 52(2), 197-211.

Balcells, L., Dorsey, S., \& Tellez, J. F. (2020). Repression and dissent in contemporary Catalonia. British Journal of Political Science, 51(4), 1742-1750. https:// doi.org/10.1017/s0007123420000307

Barrio, A., \& Barberà, O. (2006). Convergència i Unió. In A. Elias \& F. Tronconi (Eds.), From protest to power: Autonomist parties and the challenges of representation (pp. 75-98). Braumüller.

Bartkus, V. O. (1999). The dynamic of secession. Cambridge University Press.

Basta, K. (2018). The social construction of transformative political events. Comparative Political Studies, 51(10), 1243-1278.

Buchanan, A. (1991). Secession: The morality of political divorce from Fort Sumter to Lithuania and Quebec. Westview Press.

Candidatura d'Unitat Popular. (2015). Crida Constituent. Programa polític per a les eleccions al Parlament de Catalunya el 27 de Setembre de 2015 [Constituent cry. Political programme for the Catalan Parliament elections on 27 September 2015].

Candidatura d'Unitat Popular. (2017). + de 155 propostes pels drets socials, per la República i per l'Assemblea Constituent! [+ 155 proposals for social rights, for the Republic and for the Constituent Assembly!].

Convergència Democràtica de Catalunya. (2016). Fets per Catalunya. Programa electoral [Made for Catalonia. Electoral programme].

Convergència i Unió. (2012). Programa electoral 2012 [Election programme 2012].

Convergència i Unió. (2015). Farem posible el teu sí. Democracia $i$ llibertat [Making your yes possible. Democracy and liberty].

Cuadras Morató, X. (Ed.). (2016). Catalonia: A new independent state in Europe? A debate on secession within the European Union. Routledge.

Culla, J. B. (2013). Esquerra Republicana de Catalunya 1931-2012: Una història política [Esquerra Republicana de Catalunya 1931-2012: A political history]. La Campana.

Dalle Mulle, E. (2017). The nationalism of the rich: Discourses and strategies of separatist parties in Catalonia, Flanders, Northern Italy and Scotland. Routledge.

Dalle Mulle, E., \& Serrano, I. (2019). Between a principled and a consequentialist logic: Theory and practice of secession in Catalonia and Scotland. Nations and Nationalism, 25(2), 630-651.

De Winter, L., Gomez, M., \& Lynch, P. (2018). Ethnoregionalist parties. In E. Hepburn \& K. Detterbeck (Eds.), Handbook of territorial politics (pp. 139-175). Edward Elgar.

Della Porta, D., O'Connor, F., Portos, M., \& Subirats Ribas, M. (2017). Social movements and referendums from 
below: Direct democracy in the neoliberal crisis. Policy Press.

Dion, S. (1996). Why is secession difficult in wellestablished democracies? Lessons from Quebec. British Journal of Political Science, 26(2), 269-283.

Dowling, A. (2017). The rise of Catalan independence: Spain's territorial crisis. Routledge.

Elias, A. (2015). Catalan independence and the challenge of credibility: The causes and consequences of Catalan nationalist parties' strategic behaviour. Nationalism and Ethnic Politics, 21(1), 83-103.

Elias, A. (2019). Making the economic case for independence: The Scottish National Party's electoral strategy in post-devolution Scotland. Regional \& Federal Studies, 29(1), 1-23.

Elias, A., Basile, L., Franco-Guillén, N., \& Szöcsik, E. (2021). The Framing Territorial Demands (FraTerr) dataset: A novel approach to conceptualising and measuring regionalist actors' territorial strategies. Regional \& Federal Studies. Advance online publication. https:// doi.org/10.1080/13597566.2021.1964481

Esquerra Republicana de Catalunya. (2008). Objectiu: Un país de primera (per això volem la independencia) [Objective: A successful country (that's why we want independence)].

Esquerra Republicana de Catalunya. (2011). Catalunya sí. Eleccions a les Corts espanyoles 2011 [Catalonia yes. Spanish parliament elections 2011].

Esquerra Republicana de Catalunya. (2012). Un nou país. Eleccions 2012 [A new country. Elections 2021].

Esquerra Republicana de Catalunya. (2014). Comencem el \#noupais ara a Europa [Starting a \#newcountry in Europe].

Esquerra Republicana de Catalunya. (2015). El 20D defensa el teu vot [On 20D defend your vote].

Esquerra Republicana de Catalunya. (2017). La democracia sempre guanya. Eleccions al Parlament 2017 [Democracy always wins. Parliamentary elections 2017].

Gray, C. (2020). Territorial politics and the party system in Spain. Continuity and change since the financial crisis. Routledge.

Griffiths, R. D. (2020). Secessionist strategy and tactical variation in the pursuit of independence. Journal of Global Security Studies, 6(1), Article ogz082. https:// doi.org/10.1093/jogss/ogz082

Griffiths, R. D., \& Martinez, A. (2020). Local conditions and the demand for independence: A dataset of secessionist grievances. Nations and Nationalism, 27(2), 580-590. https://doi.org/10.1111/nana. 12667

Guntermann, E., \& Blais, A. (2020). When faced with elite polarization, citizens take sides: The 2017 election in Catalonia. Regional \& Federal Studies. Advance online publication. https://doi.org/10.1080/135975 66.2020.1801648

Hedgecoe, G. (2021, February 15). Socialists win most votes in Catalonia, but separatists set to maintain power. Politico. https://www.politico.eu/ article/socialists-win-most-votes-in-catalonia-butseparatists-set-to-maintain-power

Hesli, V. L., Reisinger, W. M., \& Miller, A. H. (1997). The sources of support for separatism: Public opinion in three Soviet republics. Nations and Nationalism, 3(2), 201-230.

Horowitz, D. L. (1981). Patterns of ethnic separatism. Comparative Studies in Society and History, 23(2), 165-195.

Huszka, B. (2013). Secessionist movements and ethnic conflict. Debate framing and rhetoric in independence campaigns. Routledge.

Jenne, E. K., Saideman, S., \& Lowe, W. (2007). Separatism as a bargaining posture: The role of leverage in minority radicalization. Journal of Peace Research, 44(5), 539-558.

Junts per Catalunya. (2017). Puigdemont, el nostre president [Puigdemont, our president].

Junts per Si. (2015). Programa electoral [Electoral programme].

Lecours, A. (2020). The two Québec referendums: Political strategies and international relations. In R. Griffiths \& D. Muro (Eds.), Strategies of secession and counter-secession (pp. 143-160). ECPR Press.

Liñeira, R., \& Henderson, A. (2019). Risk attitudes and independence vote choice. Political Behavior, 43, 541-560.

Martí, D., \& Cetrà, D. (2016). The 2015 Catalan election: A de facto referendum on independence? Regional \& Federal Studies, 26(1), 107-119.

Mendelsohn, M. (2003). Rational choice and sociopsychological explanation for opinion on Quebec sovereignty. Canadian Journal of Political Science, 36, 511-537.

Mitchell, J. (2016). The referendum campaign. In A. McHarg, T. Mullen, A. Page, \& N. Walker (Eds.), The Scottish independence referendum: Constitutional and political implications. Oxford University Press.

Nadeau, R., Martin, P., \& Blais, A. (1999). Attitude towards risk-taking and individual choice in the Quebec referendum on sovereignty. British Journal of Political Science, 29(3), 523-539.

Pavkovic, A., \& Radan, P. (2007). Creating new states. Theory and practice of secession. Ashgate.

Reiter, B. (2013). The epistemology and methodology of exploratory social science research: Crossing Popper with Marcuse (Government and International Affairs Faculty Publications, Article 99). http:// scholarcommons.usf.edu/gia_facpub/99

Rico, G., \& Liñeira, R. (2014). Bringing secessionism into the mainstream: The 2012 regional election in Catalonia. South European Society and Politics, 19(2), 257-280.

Saideman, S. M., \& Ayres, R. W. (2000). Determining the causes of irredentism: Logit analyses of minorities at risk data from the 1980 s and 1990s. Journal of Politics, 62(4), 1126-1144. 
Sarigil, Z., \& Karakoc, E. (2016). Who supports secession? The determinants of secessionist attitudes among Turkey's Kurds. Nations and Nationalism, 22(2), 325-346.

Scottish National Party. (2019). Scotland's future in Scotland's hands.

Sorens, J. (2005). The cross-sectional determinants of secessionism in advanced democracies. Comparative
Political Studies, 38(3), 304-326.

Sorens, J. (2008). Regionalists against secession: The political economy of territory in advanced democracies. Nationalism and Ethnic Politics, 14(3), 325-360. Statham, P., \& Trenz, H.-J. (2012). The politicization of Europe: Contesting the constitution in the mass media. Routledge.

\section{About the Authors}

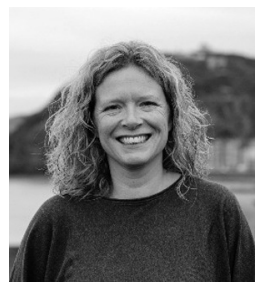

Anwen Elias is a reader in politics at the Department of International Politics, Aberystwyth University. Her research interests are comparative territorial politics and regionalist and secessionist movements in Europe. She is currently leading projects on regionalist movements' framing of their territorial demands (funded by the EU's Horizon 2020 programme) and grassroots engagement with debates about secession (funded by the UK's Economic and Social Research Council).

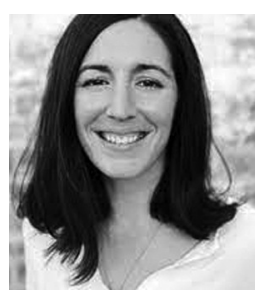

Núria Franco-Guillén is a post-doctoral fellow at the Department of International Politics (Aberystwyth University) and a member of the Interdisciplinary Research Group on Immigration (Universitat Pompeu Fabra). Her research has focused on immigration discourses in stateless nations, deliberative democracy, and regionalist movements' framing of their territorial demands. Her current work focuses on grassroots engagement with debates about secession (project funded by the UK's Economic and Social Research Council). 